\title{
THE CHANGE OF TOTAL PROTEIN FRACTION OF MUSCLE TISSUE OF PORK WITH BIO-AND PHYSICO-CHEMICAL SPECIFIC IN THE PROCESS OF COOKING AT DIFFERENT TEMPERATURES
}

\author{
ИЗМЕНЕНИЕ СУММАРНОЙ БЕЛКОВОЙ ФРАКЦИИ МЫШЕЧНОЙ ТКАНИ МЯСА \\ СВИНИНЫ С БИО- И ФИЗИКО-ХИМИЧЕСКОЙ СПЕЦИФИКОЙ В ПРОЦЕССЕ ВАРКИ \\ ПРИ РАЗЛИЧНЫХ ТЕМПЕРАТУРАХ
}

O. Shalimova, Doctor of Biological Sciences

О.А. Шалимова, доктор биологических наук

M. Radchenko, Post-graduate student

М.В. Радченко, аспирант

Orel State Agrarian University, Orel City, Russia

Орловский государственный аграрный университет, г. Орёл, Россия

Phone: +7 (910) 201-12-61, E-mail: shoked@online.recom.ru

Received March 7, 2012

\begin{abstract}
The character of changes in total protein fraction of muscle tissue of pork with PSE defects in the process of cooking at temperatures ranging from 40 to $72^{\circ} \mathrm{C}$ in steps of $2^{\circ} \mathrm{C}$ is investigated. Our studies have revealed differences in the change of state the total fraction of muscle proteins with defects PSE pork during cooking.

\section{АННОТАЦИЯ}

Исследован характер изменений суммарной белковой фракичи мышечной ткани мяса свинины с пороками PSE в проиессе варки в диапазоне температур от 40 до $72^{\circ} \mathrm{C}$ с шагом $2^{\circ} \mathrm{C}$. Проведенные исследования позволили выявить различия в изменении состояния общей фракиии мышечных белков свинины с пороками PSE в прочессе варки.
\end{abstract}

\section{KEY WORDS}

PSE-pork; Total protein fraction; Boiling; Electrophoretic separation; Molecular weight.

\section{КЛЮЧЕВЫЕ СЛОВА}

PSE-свинина; Суммарная белковая фракиия; Варка; Электрофоретическое разделение; Молекулярная масса.

Животноводческое сырье, являющееся объектом переработки предприятий мясной промышленности, сочетает в себе сложнейший комплекс свойств, предопределяющих эффективность его использования при производстве продуктов питания [6]. Повышение эффективности промышленной переработки мясного сырья, производство мясопродуктов, обеспечивающих многообразие потребительских свойств, требует расширения и углубления теоретических знаний о составе и свойствах перерабатываемого сырья и ингредиентов и их изменениях под воздействием техноло- гических факторов [5]. Особую актуальность эта проблема приобретает в условиях резко обозначившихся различий в технологических свойствах мясного сырья, относящегося к различным группам с био- и физикохимической спецификой, классифицируемых как DFD, NOR и PSE.

B научных работах широко представлены сведения о различиях в количестве и электрофоретической подвижности высоко- и низкомолекулярных фракций мышечных белков в PSE-, NOR- и DFD-мясе. Так, белок мышечной ткани свинины группы PSE в отличие от 
мяса NOR характеризуется меньшим количеством фракций с молекулярной массой 210 кДа, большей долей белковых фракций с молекулярной массой от 100 до 50 кДа, тоже наблюдается применительно к белковым фракциям с молекулярной массой от 50 до 15 кДа $[2,6]$.

Изменение структуры мышечных белков в PSE-, NOR- и DFD-мясе сказывается на их последующей денатурации. Во время термической обработки происходит денатурация большинства белков. С технологической точки зрения термическая обработка мяса необходима для доведения продукта до состояния кулинарной готовности, а также для подавления роста или полного уничтожения вегетативной микрофлоры[3]. Однако в настоящее время не выявлены закономерности деструктивных изменений мышечных белков в PSE-, NOR-и DFD-мясе под воздействием термической обработки, в частности варки.

В связи с вышесказанным исследование структуры суммарной белковой фракции в мясе свинины с различной био- и физикохимической спецификой в процессе термообработки является актуальным. Это позволит минимизировать денатурационные изменения, улучшить нежность и сочность мясопродуктов, выработанных из мясного сырья сельскохозяйственных животных, выращиваемых по интенсивным технологиям.

Целью данной работы являлось изучение суммарной белковой фракции свинины с пороками PSE в процессе варки в диапазоне температур от 40 до $72^{\circ} \mathrm{C}$ с шагом $2^{\circ} \mathrm{C}$.

Материалы и методы исследований. Объектом исследования является образцы тканей длиннейшей мышцы спины (M. longissimus dorsi) PSE-свинины, полученные от животных промышленного откорма и подвергнутые варке при различной температуре.

Концентрацию ионов водорода определяли по ГОСТ Р 51478-99 «Мясо и мясные продукты метод определения концентрации водородных ионов $(\mathrm{pH}) »$ с помощью цифрового $\mathrm{pH}$ метра с автоматической компенсацией Piccolo Plus Hi98113 (HANNA Instruments, Германия).

Перед термообработкой мясное сырье нарезали на диски (диаметр 20 мм, толщина 5 мм) и поместили в полимерные контейнеры (диаметр 21 мм, высота 15 мм, толщина стенки 0,038 мм). Мясные диски поместили в водяную баню Precisdig (SELECTA, Испания) и обрабатывали до достижения в центре образцов температуры 40, 42, 44, 46, 48, 50, 52, 54, $56,58,60,62,64,66,68,70,72^{\circ} \mathrm{C}$ (порядка 13 -15 минут).

Для получения суммарной белковой фракции пользовались методикой О.А. Усановой: 2 г предварительно измельченного мясного сырья гомогенизировали в 5 мл буферного раствора $(0,015 \mathrm{M}$ ТРИС $\mathrm{HCI}+0.15 \mathrm{M}$ $\mathrm{NaCI}, \mathrm{pH} 7,6)$, закрывали и оставляли до осаждения осадка на 20 - 30 мин, полученные гомогенаты центрифугировали при $20^{\circ} \mathrm{C}$ со скоростью 15000 об/мин в течении 30 мин на центрифуге Sigma3-18k (SIGMA, Германия). Супернатанты сохраняли, а осадки выбрасывали. Подготовленные таким образом экстракты хранили в замороженном состоянии при $-18^{\circ} \mathrm{C}$ до завершения эксперимента [4].

За основу электрофоретического разделения белков взяли стандартный арбитражный метод ISTA для белков семян гороха [1] в собственной модификации. Электрофорез белковых фракций мышечной ткани проводили в камере для вертикального электрофореза VE-4 (Helicon, США), в 12,5\% разделяющем и $5 \%$ концентрирующем геле в ТРИСглициновом электродном буфере, $\mathrm{pH} 8,3$ в присутствии додецилсульфата натрия. В качестве стандартов для ДСН-электрофореза использовали маркеры молекулярной массы белков PageRuler ${ }^{\mathrm{TM}}$, 5-250 кДа (Helicon, США).

Результаты и их обсуждение. Анализ концентрации ионов водорода, в опытных образцах мясного сырья, полученных от сельскохозяйственных животных, выращиваемых по интенсивным технологиям, показал, что в среднем $\mathrm{pH}$ составила 5,42. Это подтверждает, что опытные образцы свинины относятся к мясу с проком PSE, поскольку для свинины с признаками PSE характерны более низкие значения $\mathrm{pH}$, по сравнению с образцами NOR $-6,0-6,2$.

Электрофореграмма гомогенатов мышечной ткани длиннейшей мышцы спины PSEсвинины сваренной при $40,42,44,46,48,50$, $52,54,56,58,60,62,64,66,68,70,72^{\circ} \mathrm{C}$ приведена на рис 1. 


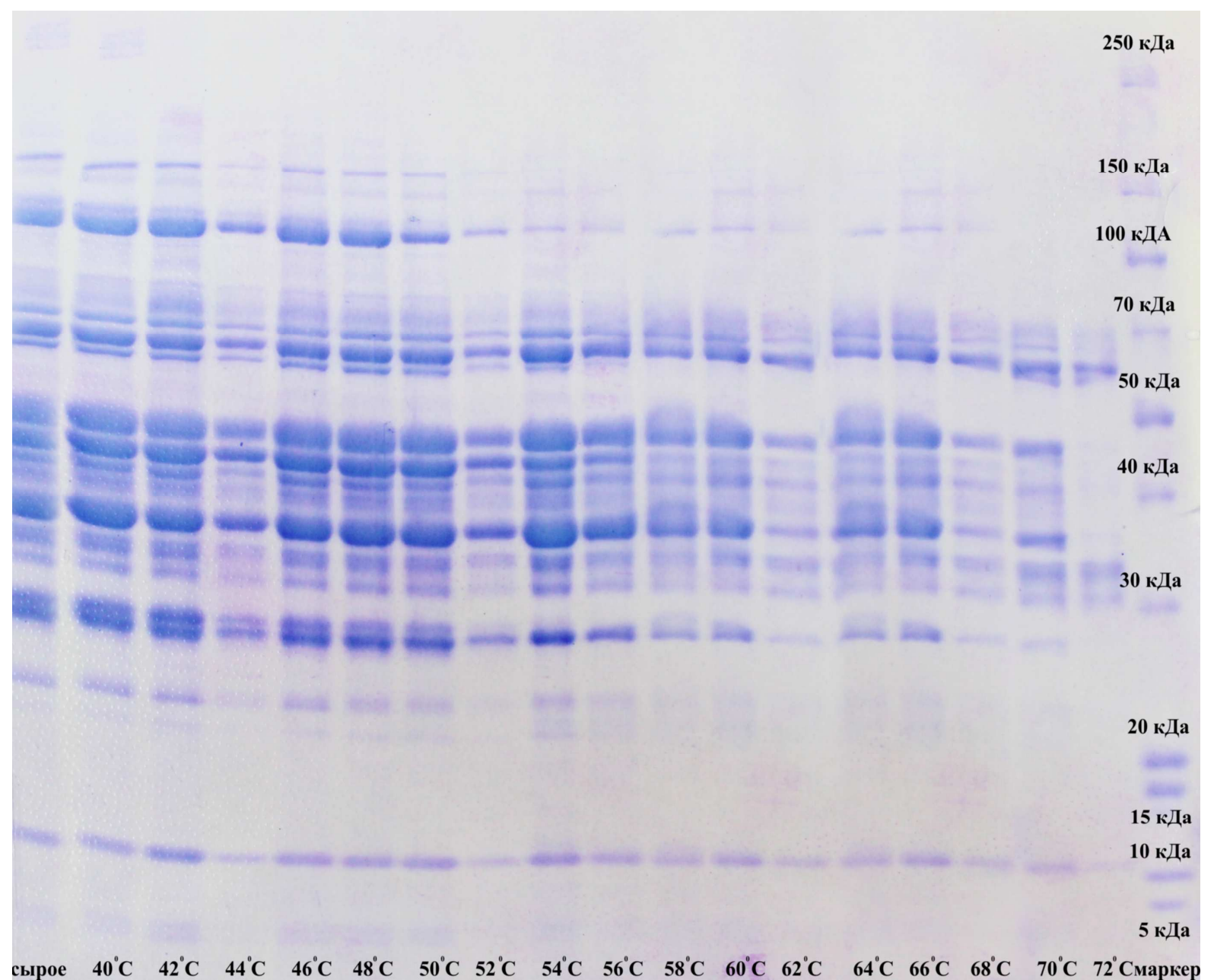

Рисунок 1 - Электрофореграмма гомогенатов мышечной ткани длиннейшей мышцы спины PSE-свинины сваренными при температуре от 40 до $72^{\circ} \mathrm{C}$ с шагом $2^{\circ} \mathrm{C}$.

Результаты электрофоретического разделения мышечных белков, извлекаемых трисовым буферным раствором с $\mathrm{pH} 7.6$, из термообработанной свинины показали достаточно четкие различия по количественному и качественному составу суммарной белковой фракции при различных температурах варки.

Исследование экстрактов мышечной ткани показало наличие слабо выраженных (минорные полосы в сырой и сваренной при $40^{\circ} \mathrm{C}$ PSE-свинине) белковых фракций с молекулярной массой более 250 кДа.

B необработанной термически PSEсвинине и PSE-свинине, сваренной при диапазоне температуре от 40 до $50^{\circ} \mathrm{C}$, можно отметить шестнадцать четко выраженных белковых фракций и четыре минорные фракции. Так, с молекулярной массой меньше 100 кДа можно визуализировать две четко выраженные белковые фракции и одну минорную, от 50 до 100 кДа - четыре белковые фракции од- на из которых минорная, наибольшее количество белковых фракций расположено в области с молекулярными массами от 20 до 50 кДа - одиннадцать, и наконец, в области низкомолекулярных белковых фракций $<20$ кДа можно отметить две белковые фракции одна из которых минорная.

При повышении тепературы обработки мяса от 40 до $50^{\circ} \mathrm{C}$ отчетливо прослеживается появление белковых фракций с молекулярной массой 150 кДа, в дальнейшем они становятся менее четко видимыми, что означает, что количество данного белка снижается (при температурах обработки от 52 до $62^{\circ} \mathrm{C}$ ). Подобной молекулярной массой обладает саркоплазматический белок - глобулин $\mathrm{X}$, а температура его денатурации колеблется в пределах в пределах $50-80^{\circ} \mathrm{C}$.

В области низкомолекурных фракций, характеризующихся относительно низкой электрофоретической подвижностью (менее 


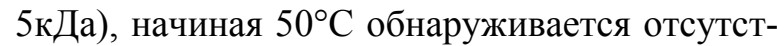
вие минорных полос. При более высоких температурах эти белки полностью подвергаются деструкции.

При $58^{\circ} \mathrm{C}$ констатируем уменьшение количества белковых средних и низкомолекулярных белковых фракций. Общее количество белковых фракций при данной температуре обработки мяса составляет одиннадцать (включая минорные). Это может быть связано с усилением денатурационных изменений как за счет повышения температуры, так и за счет активации группы протеолетических ферментов, ответственных за ферментативное гидролитическое расщепление - протеаз, катепсинов и проч.

При температуре, близкой к $72^{\circ} \mathrm{C}$, происходит денатурация белков с высокой молекулярной массой. Треки электрофореграммы при 70 и $72^{\circ} \mathrm{C}$ отличаются друг от друга количеством визуализируемых белковых фракций, так если при $70^{\circ} \mathrm{C}$ их было девять то при $72^{\circ} \mathrm{C}$ их стало пять, причем исчезли фракции с молекулярной массой в пределах от 30 до 50 кДа.

На основании полученных результатов делаем вывод, что проанализировать денатурационные изменения белков термически обработанной свинины с пороками PSE возможно с помощью фракционирования белков и дальнейшем электрофоретическом исследовании.

Выводы. Проведенные исследования позволили выявить различия в белковых спектрах суммарной фракции мышечных белков свинины с пороками PSE в процессе варки. Это позволит осуществлять модифицировать температуру обработки мясного сырья с биологической и физико-химической спецификой. Необходимо осуществлять рациональную переработку мясного сырья в соответствии с его функционально-технологическими свойствами, определяемыми состоянием белков мышечной ткани.

\section{БИБЛИОГРАФИЯ}

Гаврилюк, И.П. Электрофорез белков семян в сортовой идентификации овощных культур / И. П. Гаврилюк, Н. К. Губарева, Е. В. Смирнова, В. И. Пыженков// Аграрная Россия. - 2005. - №2. С. 20-36.

Лисицын, А.Б. Технологические аспекты повышения экзотрофической эффективности промышленной переработки мясного сырья: дис. в форме науч. доклада на соиск. уч. степ. док. тех. наук / А. Б. Лисицын - М.: 1997. -69с.

Павловский, П.Е. Биохимия мяса / П. Е. Павловский, В. В. Пальмин - М.: Пищевая промышленность, 1975. - 344c.

Усанова, О.Е. Изучение протеомных изменений мышечной ткани свинины под воздействием технологических факторов: автореф. дис. на соиск. учен. степ. канд. тех. наук / Усанова Оксана Евгеньевна; [ГНУ ВНИИ мясной промышленности им. В. М. Горбатова]. - М.: 2011. - 29с.: ил. - Библиогр.: 27-28.
Шипулин, В.И. Качество мясного сырья и проблемы его переработки /В. И. Шипулин //Вестник СевКавГТУ. - 2006. - № 1 (5). С. 36-39

Шипулин, В.И. Принципы разработки альтернативных вариантов рациональных технологий мясных продуктов нового поколения с адаптированными пищевыми добавками: 05.18.04 «Технология мясных, молочных, рыбных продуктов и холодильных производств»: автореф. дис. на соиск. учен. степ. док. тех. наук / Шипулин Валентин Иванович; [ГОУ ВПО Северо-Кавказский государственный технический университет]. - Ставрополь: 2009. - 44c.: ил. - Библиогр.: 40-44. 